Considered as a whole, the cases involving "personal" ar.d "inherent" defenses show no strong policy either in favor or against the surety; nor can it be said under most circumstances that the business content of the suretyship idea is so clear as to make one bias more consistent with usage than another. The fact is that no one knows against what risks sureties in general are supposed to protect creditors. Careful lawyers can build persuasive records pointing to the desired construction of the contract in issue, but there seems no basis either in law or in business to support a generalized theory of the uncompensated surety's risks, and no reason to look for one, with the apparatus of simple contract analysis ready at hand to deal with individual bargains as they are litigated.

\title{
DECLARATORY DECISIONS IN CRIMINAL LAW
}

Persons threatened with prosecution. under criminal legislation ${ }^{1}$ or under the numerous quasi-criminal statutes which attempt to enforce regulatory measures through forfeitures or penalties ${ }^{2}$ have found the declaratory judgment a convenient method, under certain circumstances, for adjudicating their rights before being prosecuted. Lately, however, some decisions indicate that the operation of the declaratory judgment may be so circumscribed by rules which limit the use of the injunction in criminal or quasi-criminal cases as to reduce the utility of the declaratory judgment as a procedural reform. $^{3}$ Two recent New York cases are illustrative. The first of these

1. Xfultnomah County Fair Ass'n v. Langley, 140 Ore 172, 13 Pac (2d) 354 (1932); Lagoon Jockey Club v. Davis County, 72 Utah 405, 270 Pac. 543 (1928); Harcourt v. Attorney-General [1923] N. Z. 686.

2. Sage-Allen Co., Inc. v. Wheeler, 119 Conn. 607, 179 Atl. 195 (1935); State v. Grove. 109 Kan. 619, 201 Pac. 82 (1921); Little v. Smith, 124 Kan. 237, 257 Pac. 959 (1927) ; Ware v. Ammon, 212 Ky. 152, 278 S. W. 593 (1925) ; Faulkner v. City of Keene, 85 N. H. 147, 155 Atl. 195 (1931); Chung Jfee Restaurant Co. v. Healy. 86 N. H. 483, 171 Atl. 263 (1934); Tirrell v. Johnston, 86 N. H. 530, 171 Atl. 641 (1934) ; Socony-Vacuum Oil Co. v. City of New York, 247 App. Div. 163, 237 న. Y. Supp. 288 (1st Dep't 1936); American Trust Co. v. McCallister, 136 Ore. 338. 299 Pac. 319 (1931) ; Huber r. Weakland. 7 Pa. Dist. \& Co. Rep. 496 (1925); Lindsey v. Drane, 154 Tenn. 458, 285 S. W. 705 (1926); Parlor v. Buckner, 156 Tenn. 278. 300 S. W. 565 (1927) ; State v. Henry, 218 Wis. 302,260 N. W. 486 (1935); Dysøn r. Attorney-General [1912], 1 Ch. 158; Jinister of Customs v. MfeParland, 29 N. Z. 279 (1909); Grubner v. Wright, [1921] N. Z. 394. See also Pathé Exchange, Ine v. Cobb, 202 App. Div. 450, 195 N. Y. Supp. 661 (3d Dep't 1922), aff'd, 236 N. Y. 539. 142 N. E. 274 (1923) (submission of a controversy on an agreed statement of lacts pursuant to N. Y. Civ. Prac. ACt \$546). See Borcisard, Dectaratory Judgerests (1934) $562-3$.

3. It has been argued that the declaratory judgment is simply a minor pleading reform because it adds little to what without it could be accomplished through an injunction. See Arnold, Trial By Combat and the lezu Deal (1934) 47 Harv. L. Rev. 913, 926 . 
was an action against the police commissioner of New York City, in which the manufacturer of a special type of slot machine petitioned for a declaratory judgment holding that his machines neither were nor could be conrerted into gambling devices in violation of a state penal law, and for an injunction restraining the clefendant from interfering with these machines. The trial court, although refusing the injunction, granted declaratory relief, but was reversed by the Appellate Division on the ground that a declaratory judgment should not be given where, as here, its use would circumvent the rule that equity will not, except under most untusual circumstances, enjoin the enforcement of a valid criminal statute. 5 This result was affirmed by the Court of Appeals in a per curiam opinion holding the declaratory judgment not an appropriate remedy. ${ }^{6}$ In the second case an action was brought against the police of Garden City to determine by declaratory judgment whether the plaintiff's system of dog racing violated the state penal law. The trial court declared the system legal, ${ }^{7}$ but the Appellate Division reversed, refusing to grant declaratory relief, first because it was improper for a civil court to decide whether the scheme was in violation of the penal law, and second, because a civil court's ruling on a question of the plaintiff's guilt or innocence could have no binding effect, such questions being reserved for the exclusive determination of criminal courts. ${ }^{8}$

The implication of these decisions is that the New York courts intend to regard the declaratory judgment as alternative to injunctive relief in criminal cases, and to include it within the scope of their policy against

This charge has been vigorously denied. See Borchard in note 21 in Arnold, Trial By Combat and the $N^{N}$ ew Deal (1934) 47 Harv. L. Rev. 913, 927. And in several recent cases declaratory judgments have been granted although injunctions have been refused. F. G. Vogt \& Sons, Inc. v. Rothensies, 11 F. Supp. 225 (E. D. Pa. 1935); Penn v. Glenn, 10 F. Supp. 483 (W. D. Ky. 1935); Black v. Little, 8 F. Supp. 867 (E. D. Mich. 193t) ; Interstate Natural Gas Co. v. Gully, 8 F. Supp. 174 (S. D. Miss. 1934) ; Socony-Vacuum Oil Co. v. City of New York, 247 App. Div. 163, 287 N. Y. Supp. 288 (1st Dep't 1936) ; Associated Industries v. Department of Labor, 158 Misc. 350, 286 N. Y. Supp. 459 (Sup. Ct. 1936); Lindsey v. Drane, 15+ Tenn. 458, 285 S. W. 705 (1926).

4. International Mutoscope Reel Co. v. Valentine, 247 App. Div. 130, 132, 286 N. Y. Supp. $806,807-808$ (1st Dep't 1936) (summarizing unreported decision of trial court).

5. International MLutoscope Reel Co. v. Valentine, 247 App. Div. 130, 286 N. Y. Supp. 806 (1st Dep't 1936).

6. International Mutoscope Reel Co. v. Valentine, 271 N. Y. 622, 3 N. E. (2d) 453 (1936).

7. Reed v. Littleton, 159 Misc. 853, 289 N. Y. Supp. 798 (Sup. Ct. 1936).

8. Reed v. Littleton, 292 ‥ Y. Supp. 363 (2nd Dep't 1936). For a criticism of this holding see Borchard, Letter to Editor in N. Y. L. J., Feb. 5, 1937, p. 620, col. 3.

It is to be noted that in neither of the instant cases had the threatened criminal prosecutions actually been instituted. And in the subsequent discussion the assumption is that no such action has been brought. Were it otherwise, a civil court would doubtless decline to interfere with a criminal court's jurisdiction. 
equity decisions on questions of criminal law. ${ }^{8}$ Such an extension of the rule seems to require a reconsideration of the policy underlying it. ${ }^{10}$

It is often asserted that equity will not interfere with the enforcement of a criminal law by enjoining the police from prosecuting defendants for activities which they, as petitioners in equity before the prosecution has begun, allege are not illegal. ${ }^{11}$ Although many injunctions have been denied by the application of this formula, the various exceptions which have been developed indicate that strict compliance with the general rule would have produced results thought to be too rigorous. ${ }^{12}$ Injunctions have been issued to restrain impending prosecutions which threaten "irreparable" injury to property rights if unfounded. ${ }^{13}$ The same result follows where a number of vexatious criminal prosecutions impend ${ }^{14}$ or where statutory penalties are so formidable as to deter a person subject to them from risking a criminal prosecution to test the validity of a statute. ${ }^{15}$

Several rationalizations have been advanced to support the denial of injunctions against the enforcement of the criminal law. The less persuasive among them are that the issuance of an injunction would permit the state

9. Other cases reveal the same tendency: Bradley Lumber Co. v. National Labor Relations Board, 84 F. (2d) 97 (C. C. A. 5th, 1936); Lyttle v. Valentine, 160 Misc 355, 290 N. Y. Supp. 11 (Sup. Ct. 1936).

10. It is beyond the scope of this comment to consider whether a distinction should be drawn between actions to test a statute's constitutionality and actions merely to determine its applicability. Some have argued that extra-legal considerations render it desirable to differentiate between the two cases. Those taking this position urge that the difficulty of access to the courts in constitutional cases should be maximized in order to delay judicial decisions on statutes until their operation affords sufficient experience by which to judge their social feasibility or inutility. See Note (1932) $45 \mathrm{HAsv}$. L. Rev. 1089; Shulman. Book Review (1937) to Yale L. J., 724, 725.

Others have as rigorously argued that especially in the field of public law it is socially desirable to protect individuals irom oppressive legislation by as speedy an adjudication of their constitutional rights as possible. See Borchard. Comment (1932) 41 Y ALE L. J. 1195. For presentation of buth viewpnints, see Comment (1936) 46 YALE L. J. 255, 268-272.

Where the legislature deems it desirable. the right to a declaratory judgment may be withdrawn, as in the case of federal taxes: kieder v. Rogan, 12 F. Supp. 307 (S. D. Cal. 1935); Meridian Grain \& Elevator Cu. v. Fly, 12 F. Supp. 64 (S. D. Mfiss. 1935).

11. See 5 PoMgeroy, EQuity JURISPRIDENCE (1918) $\$ 2045$.

12. See (1933) 27 ILt. L. Rev. 560, 502 .

13. Terrace v. Thompson, 263 U. S. 197 (1923); Pierce v. Society of Sisters, 268 U. S. 510 (1925).

Perhaps an exception will also be made in the case of civil rights. Ameriean Steel \& Wire Co. of N. J. v. Davis, 261 Fed. 800 (D. Ohio 1919); see Terrace v. Thompsen, 263 U. S. 197, 216 (1923).

14. Mobile v. Orr, 181 Ala. 308, 61 So. 920 (1913); Davis v. Fosnig, 128 Ind. 271,27 N. E. 726 (1891).

15. Ex parte Young, 209 L.S. 123 (1908): Terrace v. Thompson, 263 U.S. 197 (1923). 
to be sued without its consent ${ }^{115}$ and that equitable relief should be denied since the petitioner has an adequate remedy at law in his defense to the criminal prosecution. ${ }^{17}$ There are two considerations which seem mainly to linit equity juriscliction in this field: one is an unwillingness to interfere tou directly with police administration, ${ }^{18}$ the second, a reluctance to permit in a non-criminal proceeding a trial of facts pertinent to criminal responsibility without the traditional safeguards of the criminal law. ${ }^{10}$

The only persuasive argument against the granting of injunctions in these cases is the one based upon the policy which is said to require that equity should not impele criminal law enforcement. Sovereign immunity from suit should not bar equitable relief; for it is settled that a public official does not represent the state when he acts either without authority or with apparent authority, but under an invalid statute. ${ }^{20}$ Nor can it be maintained that the remedy at law is adequate: for even though acquitted, an individual may find that the uncertainties raised by the criminal prosecution have been sufficient to mar his reputation and endanger his business enterprise. ${ }^{21}$. Consequently, a speedy adjudication on legality in a civil forum appears to him far more sensible and practical than either subjecting himself to the rigors of a prosecution or, in the alternative, foregoing the exercise of his rights. And finally, the argument that the issue of criminal guilt or innocence should

16. Purity Oats Co. v. State, 125 Kan. 558, 264 Pac. 740 (1928); cf. Fitts v. MIcGhec, 172 U.S. 516 (1899).

17. Royal Farms Dairy v. Wallace. 7 F. Supp. 560 (D. MId. 1934); Book Binders' Trade Ass'n., Inc. v. Book Manufacturers' Institute, Inc., 7 F. Supp. 847 (S. D. N. Y. 1934), noted in (1935) 3 Gro. IVAsh. L. Rev. 248; Shredded Wheat Co. v. City of Elgin, 284 Ill. 389,120 N. E. 248 (1918) ; Stewart v. Herten, 125 Neb. 210,249 N.W. 552 (1933) and cases cited therein: see also cases cited in Note (1933) 87 A. L. R. 1219.

But under many declaratory judgment acts the availability of another remedy is immaterial, see, i.c., Sec. 1 of the federal act, 48 Stat. 955, 28 U. S. C. $\S 400$ (1934); In $\mathrm{New}$ York. however, the declaratory judgment is discretionary in that the court may withhold declaratory relief if it believes that the parties should be left to existing remedies. Cin. Prac. ACt $\$ 473$. Civ. Prac. Rulle 212. Connecticut has a similar discretionary rule. Coxx. Pr.sctice Book (1934) \$250(c).

18. E.r parte State e.r rcl. Mfartin. 200 Ala. 15, 75 So. 327 (1917) ; Joyner v. Hammond. 199 Iowa 919. 200 N. W. 371 (1924) ; Delaney v. Flood, 183 N. Y. 323,76 N. E. 209 (1906) ; Buffalo Gravel Corp. v. MLoore, 201 App. Div. 242, 194 N. Y. Supp. 225 (fth Depit 1922) : Kelly v. Comner, 122 Tenn. 339, 123 S. W. 622 (1909).

19. Delaney v. Flood. 183 ㄱ. Y. 323, 76 N. E. 209 (1906) ; Kelly v. Conner, 122 Tenn. 339. 123 S. II. 622 (1909): see (1932) 31 MIICI. L. REv. 128; cf. Dreiser v. Iane Co., 183 App. Div. 773. 171 N. Y. Supp. 605 (1st Dep't 1918); Lyttle v. Valen:ine. 160 Misc. 355, $290 \mathrm{\lambda}$. Y. Supp. 11 (Sup. Ct. 1936).

20. Poindexter v. Greenhow, 114 U.S. 270 (1885); Ex parte Young, 209 U.S. 123 (1908); Philadelphia Co. v. Stimson, 223 U.S. 605 (1912); Greene v. Louisville I. R. Co., 244 U.S. 499 (1917).

21. See (1927) 25 MI ICH. L. Rev. 892, 896; (1931) 6 WASH. L. Rev. 131, 134. Morecter, under most declaratory judgment acts the adec(uacy or inadequacy of legal remedies is immaterial. See Porchird, Declaratory Judgarexis (1934) 138. 
be confined to a criminal court, with its historic safeguards for the accused, is not persuasive when applied to suits for injunctions. Injunctions are sought voluntarily by those persons for whose protection the safeguards of the criminal are urged; the facts involved in these suits are usually either quite simple or even undisputed; and an adjudication that there has been a violation of the criminal law results in a penalty no more serious than the dismissal of the bill. 2 The belief, however, that an injunction may unduly interfere with the activities of the police appears well-founded. Although an injunction will restrain the police from proceeding only, where they lack probable cause or do not act in good faith, the threat of a possible citation for contempt for violating the injunction may deter authorities from instituting criminal proceedings made proper by a change in circumstances following the issuance of the injunction. ${ }^{23}$

When the police have threatened a business man with prosecution and he seeks a declaration that his business or his way of conducting it is privileged, a different situation is presented. A declaration against the police is hardly effective to throttle their efforts if they suspect a change in circumstances has rendered the declaration inapplicable. If they do prosecute and if it is held that the prosecution was unjustified, in view of the declaration, there will be no citation for contempt; for if the prosecution fails to uncover facts which were not brought out in the suit for the declaration, that declaration will be res adjudicata on the innocence of the accused, 24 and the only penalty imposed upon over-zealous police is the effort wasted in their unsuccessful prosecution. But as the police themselves are often doubtful, the decision, on the initiative of the threatened citizen, serves the same purpose as would a criminal prosecution. Hence a prosecution is unlikely.

The declaratory judgment is a comparatively new remedy in the Linited States and it seems inadvisable to confuse its development by surrounding

22. A finding of illegality in a civil court should have no bearing on the trial of the same issue in a criminal court; for in criminal proceedings guilt must be proven beyond a reasonable doubt, whereas in a civil action a fair preponderance of evidence is sufficient. Because of this difference in measure of proof a civil court's finding of facts constituting illegality can have no bearing on the same issue in a criminal court. State v. Bradnack, 69 Conn. 212 (1897); Riker v. Hooper, 35 Vt. 457 (1862); see 2 Freemar, Judgarests (5th ed. 1925) $\$ 656$. Even where the facts are stipulated in the civil action, the court's finding of illegality on the basis of law could result in no criminal penalties; for even in criminal law an adverse decision on a demurrer does not generally operate as a conviction. See Clark, Crommal. Procedure (2nd ed. 1918) $427,437$.

23. See (1927) 25 Micr. L. Rev. 892, 896.

24. No cases have been found holding a civil court's adjudication of legality res adjudicata on the same matter in a criminal court. If, however, the criminal prosecution were based upon substantially the same facts as those previously found in the civil irial, it would appear either that the prosecution should be dismissed, or, if it had proceeded to conviction, the conviction reversed on the ground of res adjudicato. 
its application with the cletailed rules which limit the availability of injunctions against criminal prosecutions. It can hardly be maintained that a declaration that certain activities are legal unduly interferes with the aclministration of the criminal law. On the contrary, where the facts are either simple or undisputed, as they normally are in these suits, the declaration will provide a more efficient administration of the criminal law without preventing the police from prosecuting should they have good cause to believe that subsequent events make prosecution proper. The alleged adequacy of a remedy at law in the guise of a defense to the criminal prosecution sliould have no relevance to the declaratory judgment, ${ }^{25}$ and the other arguments urged in support of the rule that equity should not enjoin criminal prosecution are even less persuasive when applied to the declaratory judgment than to the injunction.

The processes of the criminal law, designed to provide safeguards for the individual against governmental oppression, have become too crystallized to permit the flexibility that has been increasingly demanded; and effective competition of alternative procedures is encroaching upon the jurisdiction of the traditional criminal law. Juvenile courts, administrative tribunals, and licensing authorities have in recent decades increasingly supplanted criminal prosecution in their respective fields. ${ }^{20}$ In the area of criminal law where it can be invoked, the declaratory judgment provides another teclmique for simplification and reform of the criminal law.

In denying declaratory judgments in these cases the New York courts are preventing a speedy arljudication of rights and remitting the parties to a less efficient procedure. The fact that the two New York cases involved activities whose legality was cloubtful under gambling statutes should not be a reason for refusing a declaration: for it can hardly be said that those activities so violated fundamental canons of propriety that the courts should decline to pass upon their legality unless the issue is forced upon them in an appeal from a conviction. ${ }^{2 i}$ Other courts have granted declaratory relief in suits of a crim:nal $* *$ or quasi-criminal ${ }^{29}$ nature, and the grounds given

25. See Borchard, Declaratory Judgients (1934) 138.

26. See Warner and Cahot. Changes in the Administration of Criminal Justice During the Past Fifty Years (1937) 50 HARv. L. REv. 583, 609-615.

27. Where the alleged offense runs violently counter to established communal mores, courts are not likely by means of a declaratory judgment to aid a party to discover a method for evading the letter of such a statute. Cf. Green v. Hart, 41 F. (2d) 855 (D. Conn. 1930); White v. Hesse, 48 F. (2d) 1018 (Ct. of Appeals, D. C. 1931); Triangle Mint Corp. v. Mulrooney. 257 N.Y. 200 (1931); Times Amusement Corp. v. Mross, (Sup. Ct. 1936) X. Y. L. J., Feb. 5, 1936, p. 655, col. 5.

28. See cases cited supra note 1 and in addition the following injunction cases which in effect granted declaratory relief in criminal cases: Ashcraft v. Healey, $23 \mathrm{~F}$. (2d) 189 (C. C.A. 5th, 1927); Chambers v. Bachtel. 55 F. (2d) 851 (C. C. A. 5th, 1932); Boynton v. Ellis, 57 F. (2d) 665 (C. C. A. 10th. 1932); Davies v. Mills Novelty Co., 70 F. (2d) 424 (C.C. A. 8th, 1934): Durant v. Bemnett, 54 F. (2d) 634 (W.D. S. C. 1931); Mills Novelty Co. v. Farrell, 3 F. Supp. 555 (D. Conn. 1933); Mills 
in the two New York cases denying the declaration are not persuasive. While the restriction announced in those two cases may be criticized as too broad, sound discretion ${ }^{30}$ may occasionally dictate the denial of relief where a declaratory judgment will not terminate the issue and will, therefore, serve no useful purpose. ${ }^{31}$ This situation may be presented where the facts are either so complicated, ${ }^{32}$ so disputed, ${ }^{33}$ or so readily subject to change as to provide no assured basis for declarations upon which the parties may rely with a reasonable degree of certainty. Such flexibility in factual background might have been made the basis of the result in the first New York case involving a slot machine consisting of a small crane; for the rearrangement of a few levers might conceivably have transformed a legal game of skill into an illegal game of chance. ${ }^{34}$

Novelty Co. v. Bolan, 3 F. Supp. 968 (E. D. N. Y. 1933) ; Pure Mrint Co. v. La Barre, 96 N. J. Eq. 186, 125 At1. 105 (1924); In Matter of Shapiro, 245 App. Div. 835 (2nd Dep't 1935); Constantine v. City of New York, 116 Mlisc 349, 190 N. Y. Supp. 372 (Sup. Ct. 1921).

29. See cases cited supra note 2.

30. The granting or withholding of a declaratory judgment rests in the sound judicial discretion of the court. See N. Y. CIV. Prac. Rule 212; Automobile Equipment, Inc. v. Trico Products Corp., 11 F. Supp. 292 (W. D. N. Y. 1935); James v. Alderton Dock Yards, 256 N. Y. 298, 176 N. E. 401 (1931); see (1932) 32 CoL L. REY. 536, 537.

31. See Borchard, The Declaratory Judgment in the United States (1931) $37 \mathrm{~W}$. VA. L. Q. $127,139$.

32. Declaratory judgments are more suited to cases where the facts are simple. See New Discoveries v. Wisconsin Alumni Research Foundation, 13 F. Supp. 596. 599 (W. D. Wis. 1936); see Borchard, Comment (1932) 41 Y ALE L. J. 1195, 1203.

33. See James v. Alderton Dock Yards, Ltd., 256 N. Y. 298, 176 N. E. 101, 402 (1931) ; Lyttle v. Valentine, 160 Mfisc. 355, 290 N. Y. Supp. 11, 14 (Sup. Ct. 1935).

34. In an unpublished opinion in the trial court Mr. Justice' Steuer said: "What is a clear legal right is not as clear as the phrase, but I take it to mean that the machine must be of such a character that it cannot possibly be operated to violate any section of the Penal Law." (reported in Lyttle v. Valentine, 160 Jfise 355, 358, 290 N.Y. Supp. 11, 15 [Sup. Ct. 1936]). Apparently the two appellate courts were convinced that the machine could readily be converted into an illegal gambling device. 